\title{
Allozyme polymorphism at the $\alpha$ Gpdh and Adh loci and fitness in Drosophila melanogaster
}

\author{
J. I. Izquierdo and \\ J. Rubio
}

\author{
Department of Functional Biology (Genetics), \\ Departamento de Biologia Functional, \\ Area de Genética, University of Oviedo, \\ Universidad de Oviedo, 33071 Oviedo. Spain.
}

\begin{abstract}
We have studied in Drosophila melanogaster the effects of allozyme variation at the $\alpha$ Gpdh and Adh loci on the following fitness components: female fecundity, egg hatchability, egg-to-adult survival under near-optimal and competitive conditions, rate of development under near-optimal and competitive conditions, and mating capacity of males. Significant effects of the $\alpha G p d h$ locus on rate of development under competitive conditions (SS $>$ FS $>S S$ ), and of the $A d h$ locus on egg hatchability (FF $=S S>F S)$ and egg-to-adult survival under competitive conditions $(F F>S S=F S)$ were revealed. Possible natural selection mechanisms involved in the maintenance of allozyme polymorphisms at the $\alpha G p d h$ and $A d h$ loci are described. These mechanisms and the fitness of In(2L)t may account for the persistence and clinal distribution of the two allozyme polymorphisms in nature.
\end{abstract}

\section{INTRODUCTION}

The existence of some "in vitro" differences between the allozymes of the $\alpha G$ pdh (Miller et al., 1975) and Adh loci (Rasmuson et al., 1966; Gibson, 1970; Vigue and Johnson, 1973; Day et al., $1974 a, b$; Oakeshott, 1976) is well documented.

Nevertheless, to prove the physiological "in vivo" repercussions of these differences is not easy, and their reported relationships with environmental variables such as temperature and alcohol substrates is not very clear.

Temperature. The results obtained in experimental populations are not very coherent (Berger, 1971; Van Delden et al., 1978; Alahiotis and Pelecanos, 1980; Vigue et al., 1982; Sánchez and Rubio, $1983 a$, b; Oakeshott et al., 1985; Kohane and Parsons, 1986). The latitudinal clines for the $\alpha G p d h$ and $A d h$ loci are well established (Oakeshott et al., 1982, 1984b) but Oakeshott et al. (1982) clearly reject the positive correlation between maximum temperatures and genic frequencies at the $\alpha G p d h$ and $A d h$ loci. Besides, Gionfriddo and Vigue (1978) do not find any correlation between environmental temperature and temporal allelic frequency fluctuation at the $A d h$ locus. Thus, it seems that the relative thermostabilities of the $\alpha \mathrm{GPDH}$ and $\mathrm{ADH}$ allozymes have a small direct effect over the temperature tolerance in Drosophila melanogaster (Oakeshott et al., 1982). On the other hand, adult survival (Schenfeld and McKechnie, 1979) and larva-to-adult viability (CharlesPalabost, 1982) of the three $\alpha G p d h$ genotypes are not temperature dependent, although there is evidence of heterozygote disadvantage at high temperature (McKechnie et al., 1981).

Environmental alcohol. For the Adh locus, adult survival tests do not yield conclusive results (Briscoe et al., 1975; Oakeshott, 1976; Van Delden et al., 1978), although almost always the $F / F$ genotype is more resistant and the $A d h-F$ allele frequericy grows in experimental populations. Even so, the key to alcohol detoxification does not depend exclusively upon the ADH catalysis (McKenzie and Parsons, 1974; Oakeshott, 1976; McKenzie and McKechnie, 1978; Gibson et al., 1981; Van Delden and Kamping, 1983; Oakeshott et al., 1984a; Kerver and Van Delden, 1985; Gibson and Wilks, 1988).

In a first approximation to the topic we have carried out experiments at constant temperature and in a standard medium lacking alcohol, in order to estimate the allozyme fitnesses without the influence of these factors.

The $\alpha G p d h$ and $A d h$ loci are in chromosome II and a linkage disequilibrium associated with the cosmopolitan In $(2 \mathrm{~L}) \mathrm{t}$ has been detected between them. The $\operatorname{In}(2 \mathrm{~L}) \mathrm{t}$ includes the $\alpha G p d h$ locus but 
not the Adh locus, although the latter is near one of the two extremes of the $\operatorname{In}(2 \mathrm{~L}) \mathrm{t}$. The association between $\operatorname{In}(2 \mathrm{~L}) \mathrm{t}$ and the $\alpha G p d h-F$ and $A d h-S$ alleles is common (Watanabe and Watanabe, 1977; Inoue et al., 1984). The meaning of these nonrandom associations is subject to contradictory interpretations: for some (Prakash and Lewontin, 1968, 1971; Dobzhansky, 1970) they are clear examples of selective coadaptation; for others (Nei, 1975; Nei and Li, 1975, 1980) they can be explained as random genetic drift or as a disequilibrium of the initial linkage when the inversion took place and are, therefore, compatible with allelic neutrality.

In this work we try to infer possible natural selection mechanisms upon allozyme polymorphisms at the $\alpha G p d h$ and the $A d h$ loci, estimating several fitness components. We also try to account for the persistence and clinal distribution of the two allozyme polymorphisms in nature as functions of the obtained fitness data.

\section{MATERIALS AND METHODS}

Drosophila melanogaster flies were collected at Los Areneros near Oviedo (Asturias, North of Spain) using banana baited traps. The collected males were immediately assayed by electrophoresis whereas each female was placed in a vial with standard Drosophila medium. When larvae or pupae were present in the vials, females were also assayed by electrophoresis.

The electrophoretical analysis for $\alpha \mathrm{GPDH}$ and ADH enzymes were carried out using standard starch gel electrophoresis (Grell et al., 1965; Grell, 1967; O'Brien and MacIntyre, 1969). Two allozymes for each locus were detected: $\mathrm{F}$ (fast) and $\mathrm{S}$ (slow).

Following the Marinkovic and Ayala $(1975 a, b)$ method, single-pair crosses were made within each isofemale strain. When both parents were identical homozygote, $F F$ or $S S$ at each locus, their descendants ( $F F$ or $S S$ homozygotes at the two loci) were maintained by mass culture to constitute an original double-homozygote isofemale strain. We produced 12 isofemale strains of the FFFF genotype (group A), 12 of the FFSS genotype (B), 12 of the SSFF genotype (C), and six of the SSSS genotype (D) (from now on the first locus is always $\alpha G p d h$ and the second, $A d h$ locus). Each of these 42 isofemale strains came from a different inseminated wild female and, therefore, each retain the variability from the chromosomes of one male and one female.
To test each genotype in a genetic background representative of the genetic composition of the original population (Marinkovic and Ayala, $1975 a, b)$, series of crosses were made between the original isofemale strains, as follows. If the strains of group $A$ are represented as $A_{1}, A_{2}, A_{3}$, etc., we first crossed $A_{1} \times A_{2}, A_{2} \times A_{3}$, etc.; then we crossed $A_{1,2} \times A_{3,4}, A_{2,3} \times A_{4,5}$, etc. The same for the groups $B$ and C. Within group $D$, we crossed $D_{1-4} \times D_{5,6}$, $D_{2-5} \times D_{6,1}$, etc. Thus, within each group we have obtained six combined strains, each originated from four isofemale strains in the groups A, B and $\mathrm{C}$, and from the six isofemale strains in group $\mathrm{D}$. To obtain the homozygous or heterozygous final synthetic strains, we crossed the combined strains of same $\left(A_{1-4} \times A_{6-9}\right.$, or $B_{2-5} \times B_{9-12}$, or $C_{5-8} \times C_{10-1}$, or $D_{1-6} \times D_{2-5}$, etc. $)$ or different genotype $\left(A_{1-4} \times\right.$ $\mathrm{B}_{1-4}$, or $\mathrm{B}_{5-8} \times \mathrm{C}_{5-8}$, or $\mathrm{C}_{9-12} \times \mathrm{D}_{3-2}$, etc.), respectively (table 1). Thus, we obtained 30 final synthetic strains, three of each of the ten possible genotypic combinations. Each of these final synthetic strains is derived from six, eight or ten original isofemale strains and the three final synthetic strains of same genotype join genetic background come from 6 , 12,18 or 24 original isofemale strains (table 1 ).

Table 1 Crosses to originate the 30 final synthetic strains, three strains of each genotypic combination

\begin{tabular}{|c|c|c|c|}
\hline Genotypes & Crosses & & \\
\hline$\frac{F F}{F F}$ & $A_{1-4} \times A_{6-9}$ & $\mathbf{A}_{2-5} \times \mathbf{A}_{9-12}$ & $\mathbf{A}_{5-8} \times \mathbf{A}_{10-1}$ \\
\hline$\frac{F F}{F S}$ & $A_{1-4} \times B_{1-4}$ & $\mathrm{~A}_{5-8} \times \mathrm{B}_{5-8}$ & $A_{9-12} \times B_{9-12}$ \\
\hline$\frac{F S}{F S}$ & $B_{1-4} \times B_{6-9}$ & $\mathrm{~B}_{2-5} \times \mathrm{B}_{9-12}$ & $\mathrm{~B}_{5-8} \times \mathrm{B}_{10-1}$ \\
\hline$\frac{F F}{S F}$ & $A_{2-5} \times C_{2-5}$ & $\mathrm{~A}_{6-9} \times \mathrm{C}_{6-9}$ & $\mathrm{~A}_{\mathrm{t} 0-1} \times \mathrm{C}_{10-1}$ \\
\hline$\frac{F F}{S S}$ & $A_{1-4} \times D_{1-4 / 5-6}$ & $A_{5-8} \times D_{2-5 / 6-1}$ & $A_{9-12} \times D_{3-6 / 1-2}$ \\
\hline$\frac{F S}{S F}$ & $\mathrm{~B}_{1-4} \times \mathrm{C}_{1-4}$ & $\mathrm{~B}_{5-8} \times \mathrm{C}_{5-8}$ & $\mathrm{~B}_{9-12} \times \mathrm{C}_{9-12}$ \\
\hline$\frac{F S}{S S}$ & $\mathrm{~B}_{2-5} \times \mathrm{D}_{1-6 / 3-4}$ & $\mathrm{~B}_{6-9} \times \mathrm{D}_{2-1 / 4-5}$ & $\mathrm{~B}_{10-1} \times \mathrm{D}_{4-1 / 2-3}$ \\
\hline$\frac{S F}{S F}$ & $\mathrm{C}_{1-4} \times \mathrm{C}_{6-9}$ & $\mathrm{C}_{2-5} \times \mathrm{C}_{9-12}$ & $\mathrm{C}_{5-8} \times \mathrm{C}_{10-1}$ \\
\hline$\frac{S F}{S S}$ & $\mathrm{C}_{1-4} \times \mathrm{D}_{1-4 / 5-6}$ & $\mathrm{C}_{5-8} \times \mathrm{D}_{2-5 / 6-1}$ & $\mathrm{C}_{9-12} \times \mathrm{D}_{3-6 / 1-2}$ \\
\hline$\frac{S S}{S S}$ & $\begin{array}{l}D_{1-4 / 5-6} \\
\times D_{2-1 / 4-5}\end{array}$ & $\begin{array}{l}D_{1-6 / 3-4} \\
\times D_{3-6 / 1-2}\end{array}$ & $\begin{array}{l}\mathrm{D}_{2-5 / 6-1} \\
\times \mathrm{D}_{4-1 / 2-3}\end{array}$ \\
\hline
\end{tabular}


To study the $\operatorname{In}(2 \mathrm{~L}) \mathrm{t}$, the polytene chromosomes of third-instar larvae were analysed according to Levine and Schwartz (1970). Five larvae of each of 24 double-homozygote combined strains were analysed.

We estimated selection for fecundity, zygotic selection and sexual selection. Experiments did not coincide in time to avoid correlated estimations. Only viability and rate of development for each density were estimated in the same experiment.

The following fitness components were studied:

Female fecundity, estimated in two replicates with three females and four males each. The number of eggs laid by each group was counted daily during seven days (from third to ninth day of life).

Egg hatchability or egg-to-larvae viability, estimated in six replicates of 50 eggs each.

Egg-to-adult viability under near-optimal density, estimated from 20 eggs per vial in each one of ten replicates; and under competitive density, four replicates of 100 eggs per vial.

Rate of development under near-optimal density, estimated from 20 eggs per vial in each one of ten replicates; and under competitive density, four replicates of 100 eggs per vial.

Mating capacity of males, estimated in five replicates. Each replicate consisted of one male in presence of 12 virgin females during 24 hours. Afterwards, each female was placed in an

Table 2 Locus $\alpha G p d h$. Genotypic and genic frequencies in the wild females

\begin{tabular}{llrl}
\hline Genotypes & $\begin{array}{l}\text { Observed } \\
\text { number }\end{array}$ & $\begin{array}{l}\text { Expected } \\
\text { number }\end{array}$ & Frequency \\
\hline$F F$ & 73 & $55 \cdot 75$ & $0 \cdot 3188$ \\
$F S$ & 80 & $114 \cdot 48$ & $0 \cdot 3493$ \\
$S S$ & $\frac{76}{229}$ & $\frac{58 \cdot 77}{229 \cdot 00}$ & $\frac{0 \cdot 3319}{1 \cdot 0000}$ \\
\hline
\end{tabular}

Genic frequencies $\alpha G p d h-F \quad p_{\alpha}=0.4934$

$\alpha$ Gpdh-S $\quad q_{\alpha}=0.5066$ individual vial to observe if descendants appeared or not. The females came from all the synthetic strains.

All the experiments were carried out in an incubator at $24 \pm 1{ }^{\circ} \mathrm{C}$ and a $12 \mathrm{~L}: 12 \mathrm{D}$ light-darkness cycle.

Factorial analyses of variance were used. These analyses require symmetry of the data and, therefore, only one datum for double heterozygotes. In all cases we used the data corresponding to coupling heterozygotes because no significant differences were found between the two double heterozygotes for any of the components. When the data were proportions (egg hatchability, viabilities under the two densities and mating capacity of males) we applied the arcsine $\sqrt{\text { proportion }}$ transformation.

In factorial analyses of variance data of all replicates in each of the final synthetic strains were utilised. Thus, the analyses reveal if there are differences between synthetic lines of the same genotype and, therefore, if the genetic background contributes to fitness differences.

\section{RESULTS}

\section{The original population}

The 68 males and 229 females collected from the wild were assayed by electrophoresis to reveal the $\alpha \mathrm{GPDH}$ and $\mathrm{ADH}$ allozymes. Wild males and females showed no significant differences for genotypic nor allelic frequencies at the $\alpha G p d h$ locus. The same occurring at the Adh locus (Izquierdo, 1987).

Tables 2, 3 and 4 give only female data. The male combined genotype data were not available as they were used for the confirmation of other data. Therefore, from now on we will only use the female data for the Los Areneros natural population.

At the $\alpha G p d h$ locus, genic frequencies are near 0.5 the $\alpha G p d h-S$ being somewhat higher (table 2).

Table 3 Locus $A d h$. Genotypic and genic frequencies in the wild females

\begin{tabular}{|c|c|c|c|c|}
\hline Genotypes & $\begin{array}{l}\text { Observed } \\
\text { number }\end{array}$ & $\begin{array}{l}\text { Correction } \\
\text { for continuity }\end{array}$ & $\begin{array}{l}\text { Expected } \\
\text { number }\end{array}$ & Frequency \\
\hline$F F$ & 176 & $175 \cdot 5$ & $171 \cdot 18$ & $0 \cdot 7686$ \\
\hline$F S$ & 44 & $44 \cdot 5$ & $53 \cdot 62$ & $0 \cdot 1921$ \\
\hline \multirow[t]{2}{*}{$S S$} & 9 & $8 \cdot 5$ & $4 \cdot 20$ & 0.0393 \\
\hline & 229 & $229 \cdot 0$ & $229 \cdot 00$ & $1 \cdot 0000$ \\
\hline
\end{tabular}

Genic frequencies $A d h-F \quad p_{\mathrm{A}}=0.8646$

Adh $-S \quad q_{\mathrm{A}}=0 \cdot 1354$ 
Table 4 Observed and expected frequencies of two-loci combined genotypes in the wild females

\begin{tabular}{|c|c|c|c|c|c|c|c|c|}
\hline & & Adh & notype & & & & & \\
\hline & & $F F$ & & $F S$ & & $S S$ & & \\
\hline Genot & & Obs. & Exp. & Obs. & Exp. & Obs. & Exp. & Total \\
\hline & Obs. & 39 & & 26 & & 8 & & 73 \\
\hline & Exp. & & $56 \cdot 10$ & & $14 \cdot 03$ & & $2 \cdot 87$ & \\
\hline & Obs. & 65 & & 15 & & 0 & & 80 \\
\hline & Exp. & & $61 \cdot 48$ & & $15 \cdot 37$ & & $3 \cdot 14$ & \\
\hline & Obs. & 72 & & 3 & & 1 & & 76 \\
\hline 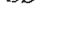 & Exp. & & 58.41 & & $14 \cdot 60$ & & $2 \cdot 99$ & \\
\hline Total & & 176 & & 44 & & 9 & & 229 \\
\hline
\end{tabular}

Genotypic frequencies differ significantly $(P<$ 0.001 ) from the Hardy-Weinberg equilibrium due to an excess of both homozygotes. The Adh-F allele frequency is much higher than that of $A d h-S$ (table 3 ) and genotypic frequencies significantly $(P<0.05)$ differ from the Hardy-Weinberg equilibrium due to an excess of both homozygotes. In this area (Asturias) it is not rare to find $D$. melanogaster populations with a deficit of heterozygotes (Izquierdo, 1987 and references therein).

On the other hand, the effective size of the Los Areneros natural population was estimated (Corrales, 1982) at about 10,000 individuals. Samples taken there over several years revealed the maintenance of allozyme frequencies (Corrales, 1982) at similar levels to those reported in this work, and the inversion frequencies (Sanchez Refusta, unpublished data) at the levels reported by Roca et al. (1982).

The FFFS, FFSS and SSFF genotypes showed higher frequencies than expected in the independent combination hypothesis, while the FFFF, FSSS and SSSS showed lower frequencies than expected (table 4). The difference between observed and expected values was significant $(P<$ 0.001). Following the Weir and Cockerham (1979) procedure, a negative $(D=-0.053)$ and highly significant $(P<0.001)$ linkage disequilibrium was observed.

We have found the $\operatorname{In}(2 \mathrm{~L}) \mathrm{t}$ in two of the six combined strains of group A (genotype FFFF) and in all the six combined strains of group $B$ (genotype FFSS). Given the constitution of these combined strains we may deduce that when the
In(2L)t appears in two combined strains, probably only one original isofemale strain would carry it. When the $\operatorname{In}(2 \mathrm{~L}) \mathrm{t}$ appears in all the six combined strains of the same group, from three to 12 original isofemale strains would carry it. Given the habitual association between $\operatorname{In}(2 \mathrm{~L}) \mathrm{t}$ and $\alpha G p d h-F$ and $A d h-S$ alleles we can assume the existence of $\operatorname{In}(2 \mathrm{~L}) \mathrm{t}$ in all the 12 original isofemale strains of FFSS genotype.

\section{Fitness components in the synthetic lines}

Female fecundity. The mean numbers of eggs laid per female and day range from 86.5 (genotype $F F F F$ ) to 96.6 (genotype $S S F F$ ). The factorial analysis of variance showed no significant differential influence of the $\alpha G p d h$ or $A d h$ loci or their interaction on this component.

Egg hatchability. Table 5 shows the mean numbers of emerged larvae. The factorial analysis of variance (table 6) showed significant $(P<0 \cdot 05)$ differential influence of the $A d h$ locus on egg hatchability. Both homozygotes exhibited higher

Table 5 Egg hatchability: Mean numbers of emerged larvae

\begin{tabular}{lllll}
\hline & \multicolumn{3}{l}{ Adh Genotypes } & \\
\cline { 2 - 4 } Gendh & \multicolumn{2}{l}{$\begin{array}{l}\alpha G p d h \\
\text { Genotypes }\end{array}$} \\
\cline { 2 - 4 } & $F F$ & $F S$ & $S S$ & $45 \cdot 9$ \\
$F F$ & $46 \cdot 2$ & $44 \cdot 8$ & $46 \cdot 8$ & $46 \cdot 2$ \\
$F S$ & $46 \cdot 1$ & $45 \cdot 8$ & $46 \cdot 7$ & $46 \cdot 4$ \\
$S S$ & $\frac{47 \cdot 2}{46 \cdot 5}$ & $\frac{45 \cdot 3}{45 \cdot 3}$ & $\frac{46 \cdot 6}{46 \cdot 7}$ & \\
\hline
\end{tabular}

Mean value of the FSSF genotype: $Y=44 \cdot 6$. 
Table 6 Egg hatchability: Factorial analysis of variance

\begin{tabular}{lcrrrr}
\hline $\begin{array}{l}\text { Source of } \\
\text { variation }\end{array}$ & $\begin{array}{l}\text { Degrees of } \\
\text { freedom }\end{array}$ & $\begin{array}{l}\text { Sums of } \\
\text { squares }\end{array}$ & $\begin{array}{l}\text { Mean } \\
\text { squares }\end{array}$ & $F$ & $P<$ \\
\hline Locus $\alpha G p d h$ & 2 & $12 \cdot 39$ & $6 \cdot 19$ & $0 \cdot 15$ & ns \\
Locus $A d h$ & 2 & $251 \cdot 49$ & $125 \cdot 75$ & $3 \cdot 08$ & $0 \cdot 05$ \\
Interaction & 4 & $39 \cdot 63$ & $9 \cdot 91$ & $0 \cdot 24$ & ns \\
Within genotypes & 153 & $6245 \cdot 91$ & $40 \cdot 82$ & & \\
Synthetic strains & 18 & $1029 \cdot 79$ & $57 \cdot 21$ & $1 \cdot 48$ & $\mathrm{~ns}$ \\
Replicates & 135 & $5216 \cdot 12$ & $38 \cdot 64$ & & \\
\hline
\end{tabular}

egg hatchability than heterozygotes. No significant differential influence could be detected either for the $\alpha G p d h$ locus nor for the $\alpha G p d h$ and $A d h$ loci interaction.

Egg-to-adult viability under near-optimal density. The mean numbers of adults arisen range from $17 \cdot 5(F S S S)$ to $18 \cdot 8(F S F F)$. Neither the $\alpha G p d h$ nor the $A d h$ loci show significant differential influence on this component. The same applies for the interaction between the loci.

Egg-to-adult viability under competitive density. Table 7 shows the mean numbers of adults arisen. The factorial analysis of variance (table 8 ) revealed a significant $(P<0.05)$ differential influence of the Adh locus on this component. Under competitive density, $A d h-F / A d h-F$ homozygotes showed a higher viability than $F S$ or $S S$ genotypęs. No significant differential influence could be detected either for the $\alpha G p d h$ locus nor for the interaction

Table 7 Egg-to-adult viability under competitive density: Mean numbers of adults emerged

\begin{tabular}{|c|c|c|c|c|}
\hline \multirow{2}{*}{$\begin{array}{l}\alpha G p d h \\
\text { Genotypes }\end{array}$} & \multicolumn{3}{|c|}{ Adh Genotypes } & \multirow{2}{*}{$\begin{array}{l}\alpha G p d h \\
\text { Genotypes }\end{array}$} \\
\hline & $F F$ & $F S$ & $S S$ & \\
\hline$F F$ & $92 \cdot 7$ & $84 \cdot 7$ & $87 \cdot 8$ & $88 \cdot 4$ \\
\hline$F S$ & $91 \cdot 8$ & $86 \cdot 2$ & $85 \cdot 3$ & $87 \cdot 8$ \\
\hline \multirow[t]{2}{*}{$S S$} & 91.9 & $88 \cdot 0$ & $88 \cdot 3$ & $89 \cdot 4$ \\
\hline & $\overline{92 \cdot 1}$ & $\overline{86 \cdot 3}$ & $\overline{87 \cdot 2}$ & \\
\hline
\end{tabular}

Mean value of the FSSF genotype: $Y=88 \cdot 1$. between the loci. The variation among synthetic strains of the same genotype was highly significant $(P<0.001)$, therefore indicating an important influence of the background; even so, allelic differences in the $A d h$ locus produced significant viability differences other than those due to genetic background.

Application of Scheffé's method (Sokal and Rohlf, 1981) to the mean values of combined twoloci genotypes revealed than the means corresponding to $F F F F, F S F F$ and $S S F F$ genotypes are significantly $(P<0.05)$ higher than the other. That is, the $A d h-F / A d h-F$ homozygotes exhibit the highest viability in all genotypic combinations with the $\alpha G p d h$ locus.

Rate of development under near-optimal density. The mean numbers of days for egg-to-adult development range from 10.83 (SSFS) to 10.99 $(F F F F)$. Neither the $\alpha G p d h$ nor the Adh loci exert significant differential influence on this component. The same for the interaction between the loci.

Rate of development under competitive density. Table 9 shows the mean numbers of days for eggto-adult development. The factorial analysis of variance (table 10) revealed a significant $(P<0 \cdot 01)$ differential influence of the aGpdh locus on this component. Under competitive density, $\alpha G p d h$ $S / \alpha G p d h-S$ homozygotes have a greater rate of development than $F S$ or $F F$ genotypes. No significant differential influence could be detected

Table 8 Egg-to-adult viability under competitive density: Factorial analysis of variance

\begin{tabular}{|c|c|c|c|c|c|}
\hline $\begin{array}{l}\text { Source of } \\
\text { variation }\end{array}$ & $\begin{array}{l}\text { Degrees of } \\
\text { freedom }\end{array}$ & $\begin{array}{l}\text { Sums of } \\
\text { squares }\end{array}$ & $\begin{array}{l}\text { Mean } \\
\text { squares }\end{array}$ & $F$ & $P<$ \\
\hline Locus $\alpha G p d h$ & 2 & $35 \cdot 13$ & $17 \cdot 56$ & $0 \cdot 26$ & ns \\
\hline Locus Adh & 2 & $583 \cdot 65$ & $291 \cdot 82$ & $4 \cdot 37$ & $0 \cdot 05$ \\
\hline Interaction & 4 & $49 \cdot 26$ & $12 \cdot 32$ & $0 \cdot 18$ & ns \\
\hline Within genotypes & 99 & $2697 \cdot 15$ & $27 \cdot 24$ & & \\
\hline Synthetic strains & 18 & $1201 \cdot 35$ & $66 \cdot 74$ & $3 \cdot 61$ & 0.001 \\
\hline Replicates & 81 & $1495 \cdot 79$ & $18 \cdot 47$ & & \\
\hline
\end{tabular}


Table 9 Rate of development under competitive density: Mean numbers (in days) for egg-to-adult development

\begin{tabular}{lllll}
\hline \multirow{4}{*}{\begin{tabular}{l}
\multicolumn{3}{l}{ Adh Genotypes } \\
Genotypes
\end{tabular}} & FF & $F S$ & $S S$ & $\begin{array}{l}\alpha G p d h \\
\text { Genotypes }\end{array}$ \\
\cline { 2 - 4 } FF & 11.95 & 12.08 & 11.99 & $12 \cdot 01$ \\
$F S$ & 11.77 & 11.88 & 11.84 & 11.83 \\
$S S$ & $\underline{11.55}$ & $\underline{11.72}$ & $\underline{11.90}$ & 11.72 \\
\hline
\end{tabular}

Mean value of the FSSF genotype: $Y=11 \cdot 75$.

either for the Adh locus nor for the interaction between the loci. The variation among synthetic strains of the same genotype is significant $(P<$ $0.05)$, indicating an influence of the background on this component; even so, the $\alpha G p d h$ locus influence produces significant differences other than those due to genetic background.

The Scheffé's procedure revealed that the $S S F F$ genotype has a significantly $(P<0.05)$ higher rate of development than the other genotypes. On the other hand, the FFFF, FFFS and FFSS genotypes have a significantly $(P<0.05)$ lower rate of development than the other; that is, homozygosity for $F$ allele in locus $\alpha G p d h$ decreases the rate of development in all the genotypic combinations with the Adh locus.

Mating capacity of males. The mean numbers of inseminated females during 24 hours range from $7 \cdot 2$ (by males from $F S F F$ genotype) to $8 \cdot 3$ (FFFS). Neither the $\alpha G p d h$ nor the Adh loci exert significant differential influence on this component. The same applies for the interaction between loci.

\section{DISCUSSION}

\section{Fitness differences among single-locus genotypes}

The number of isofemale strains involved in each final synthetic strain permit us to examine the genotypic fitnesses of studied loci with a genetical background representative of the natural population. Nevertheless, the small number of effective generations in the crosses to obtain the final synthetic strains cannot confirm whether the observed fitness differences are due to the $\alpha G p d h$ and $A d h$ loci or to others associated in linkage disequilibrium with them. But, in this case, preserved non-random associations would come from nature and, therefore, their effects would be due to factors also operating there.

$\alpha G p d h$ locus. We have found significant differential influence of this locus on the rate of development in competitive conditions at high density. The $S S$ homozygotes show a rate of development in these conditions higher than heterozygotes and $F F$ homozygotes $(S S>F S>F F)$. This is essentially in agreement with Cavener (1983). Moreover, Charles-Palabost (1982) finds that in quasi-optimal density, at $18^{\circ} \mathrm{C}$ as at $25^{\circ} \mathrm{C}$, the viabilities of the three genotypes are statistically different $(F S \geqq$ $F F>S S$ ), while the relation becomes $(S S \geqq F S>$ $F F)$ under larval competition. These results demonstrate that the temperature variation alone cannot explain the maintenance of $\alpha G p d h$ polymorphism, while the variation in density is able to reverse the relative fitness of the two homozygous genotypes. Thus, the larval density is a factor which may account for the persistence and clinal distribution of $\alpha G p d h$ polymorphism.

Adh locus. We have found significant influence of this locus on egg hatchability with a selective disadvantage of heterozygotes.

We have also found significant influence on egg-to-adult viability under competitive density. Our results agree with those of the other authors that differences can only be observed under special conditions (Morgan, 1975; Watanabe and Watanabe, 1977; Van Delden et al., 1978; Serradilla and Ayala, 1983) and that $F F$ homozygotes are more viable than $S S$ ones (Morgan, 1975; Watanabe and Watanabe, 1977; Van Delden et al., 1978) although Serradilla and Ayala (1983) did not find a significant difference between them.

Table 10 Rate of development under competitive density: Factorial analysis of variance

\begin{tabular}{llllll}
\hline $\begin{array}{l}\text { Source of } \\
\text { variation }\end{array}$ & $\begin{array}{l}\text { Degrees of } \\
\text { freedom }\end{array}$ & $\begin{array}{l}\text { Sums of } \\
\text { squares }\end{array}$ & $\begin{array}{l}\text { Mean } \\
\text { squares }\end{array}$ & $F$ & $P<$ \\
\hline Locus $\alpha G p d h$ & 2 & $1 \cdot 4718$ & $0 \cdot 7359$ & $6 \cdot 04$ & 0.01 \\
Locus $A d h$ & 2 & $0 \cdot 5123$ & 0.2561 & $2 \cdot 10$ & $\mathrm{~ns}$ \\
Interaction & 4 & $0 \cdot 4166$ & $0 \cdot 1041$ & 0.85 & $\mathrm{~ns}$ \\
Within genotypes & 99 & $7 \cdot 1953$ & 0.0727 & & \\
Synthetic strains & 18 & $2 \cdot 1932$ & $0 \cdot 1218$ & 1.97 & 0.05 \\
Replicates & 81 & $5 \cdot 0021$ & 0.0618 & & \\
\hline
\end{tabular}


Table 11 Viabilities (percentage) of the three genotypes at Adh locus

\begin{tabular}{llllll}
\hline Genotypes & Egg-to-larva (1) & Egg-to-adult ${ }^{\mathrm{a}}(1)$ & Egg-to-adult $^{\mathrm{b}}(1)$ & Larva-to-adult $^{\mathrm{a}}(2)$ & Larva-to-adult $^{\mathrm{b}}(2)$ \\
\hline$F F$ & $93 \cdot 0$ & $92 \cdot 5$ & $92 \cdot 1$ & $99 \cdot 46$ & $99 \cdot 03$ \\
FS & $90 \cdot 6$ & $90 \cdot 5$ & $86 \cdot 3$ & $99 \cdot 89$ & $95 \cdot 25$ \\
SS & $93 \cdot 4$ & $90 \cdot 0$ & $87 \cdot 2$ & $96 \cdot 36$ & $93 \cdot 36$ \\
\hline
\end{tabular}

${ }^{a}$ Under near-optimal density.

${ }^{\mathrm{b}}$ Under competitive density.

(1) Estimated in the experiment.

(2) Deduced from estimated.

Given the diversity of conditions, these coincidences are noteworthy. The relation between $F S$ and homozygotes is more variable according to the authors.

The developmental time of $F F$ genotype is shorter than $S S$ (Van Delden and Kamping, 1979) and $A d h-F$ frequency increases under selection for fast developmental $F F$ being the fittest genotype (Knibb et al., 1987).

Egg-to-adult viability can be considered as having two components: egg-to-larva and larva-toadult viabilities. Egg-to-larva (egg hatchability) and egg-to-adult viabilities were independently measured. To deduce the larva-to-adult ratios among the three genotypes we assume no influence of density on egg hatchability, at least, for densities utilised here.

Since FS genotype presents the lowest egg-tolarva viability, the absence of significant differences among egg-to-adult viabilities of the three genotypes under near-optimal conditions is only explainable if the $F S$ have, under these conditions, higher larva-to-adult viability than both homozygotes (table 11). It seems that egg-to-larva viability would be better adjusted in homozygotes although the heterozygotes would have higher larva-to-adult viability under near-optimal conditions.

Under competitive conditions, at high density, the $F F$ homozygotes are more viable than the two other genotypes. The $F F$ superiority with respect to heterozygotes could be due to the higher egg hatchability but we can see (table 11) that FF also has greater larva-to-adult viability.

The effects of $\alpha G p d h$ and $A d h$ loci have been assayed in each experimental test of fitness components and we have found a significant influence of $\alpha G p d h$ only on the rate of development and of Adh only on viability. Effects of $\alpha G p d h$ locus on viability (Charles-Palabost, 1982) and $A d h$ on rate of development (Van Delden and Kamping, 1979; Knibb et al., 1987) have been found by other authors examining only a single locus. Given the frequent association between the alternative alleles from $\alpha G p d h$ and $A d h$ loci (table 4), if the samples come from populations with similar frequencies to Los Areneros population and if the combinations with the other locus are not ramdomised because only a single locus is taken into consideration, our results suggest that the effects on viability attributed to $\alpha G p d h$ locus might be explained by the effect of $A d h$, since 95 per cent of the $\alpha G p d h$ $S / \alpha G p d h-S$ homozygotes are SSFF. In the same way, the effects of $A d h$ locus on rate of development might be due to the effect of $\alpha G p d h$ since 89 per cent of the $A d h-S / A d h-S$ homozygotes are FFSS.

\section{Two-loci combined genotypes}

For egg-hatchability one can observe (table 5) that $A d h$ heterozygosity gives the lowest three values in all genotype combinations with the other locus.

For the egg-to-adult viability at competitive density, the genotypes with homozygosity $F F$ at the Adh locus ( $S S F F, F S F F$ and FFFF) exhibit values significantly higher than the other. The greatest viability of the $A d h-F$ allele in homozygosity is shown in all combinations with the other locus alleles. On the other hand (and in the hypothesis that the Los Areneros population is under somewhat competitive conditions, at least when the sample was taken), it seems that viability would be the most decisive component in maintaining frequencies in the population, because all three combined genotypes with the greatest viability are the most frequent in the population (tables 4 and 7 ).

Contrary to what happens with viability, the influence of the rate of development on gene frequencies in the population seems to be rather scarce or, at least, indirect. Although the most frequent genotype in the population (SSFF) is the one with the significantly fastest rate of development, two of the genotypes showing a low rate of development ( $F F F F$ and $F F F S$ ) have a rather high 
frequency and only one (FFSS) is rare (tables 4 and 9). It is not easy to attribute relative selective value to fast or slow development: either fast or slow development can be advantageous depending on how conditions vary in time and space.

On the other hand, the rather high frequency of the FFFS genotype in the natural population is not in accordance with its viability and rate of development, as both are the lowest ones (tables 7 and 9). The association between FS gametes and $\operatorname{In}(2 \mathrm{~L}) \mathrm{t}$ in the Los Areneros natural population is almost complete (Corrales, 1982) and therefore the greater part of the FFFS individuals are heterozygous for $\operatorname{In}(2 \mathrm{~L}) \mathrm{t}$. Watanabe and Watanabe (1977) have demonstrated that $\operatorname{In}(2 \mathrm{~L}) \mathrm{t}$ heterokaryotypes have low viability but high productivity, which can increase their frequency in populations.

\section{Polymorphism at the $\alpha$ Gpdh and Adh loci in natural populations}

It can be stated that, at least under certain conditions, fitness differences exist between individuals having different genotypes. But it is necessary to explain the persistence in the population of lower fitness alleles and genotypes, that is, to explain how the fitness relations among the genotypes were such as to produce a stable equilibrium of allele frequencies (Lewontin, 1974). Since under nearoptimal density no significant differences appear, contrary to what occurs under competitive density, this could be one of the mèchanisms in maintaining polymorphisms at the $\alpha G p d h$ and $A d h$ loci.

On the other hand, the $\alpha G p d h-F / \alpha G p d h-F$ homozygote persists in the population due to the great viability of the $F F F F$ genotype and to the high productivity of FFFS. Moreover, the $\alpha G p d h-F$ allele is maintained in the FSFF genotype which has a great viability due to its $F F$ homozygosity for the Adh locus.

The $A d h-S / A d h-S$ homozygote persists almost exclusively in the FFSS genotype because 89 per cent of the $A d h-S / A d h-S$ genotypes are FFSS (table 3). The $A d h-S$ allele also persists in the FFFS genotype. Productivity of $\operatorname{In}(2 \mathrm{~L}) \mathrm{t}$ determines the frequencies of the FFSS and FFFS genotypes.

In this way, under competitive conditions, the $A d h-F$ allele seems to be the main element determining frequencies at the $A d h$ locus through its influence on viability. It determines to a considerable extent the allele frequencies at the $\alpha G p d h$ locus through its genotypic combinations with it. These last frequencies are modulated by the $\alpha G p d h-S$ allele influence on the rate of develop- ment. This is in accordance with the hypothesis (Oakeshott et al., 1982) that for $\alpha G p d h$, the balancing selection is more important and clinal variation in the relative fitness of the homozygotes less important than for $A d h$. This could explain the frequency levels at both loci found in the Los Areneros population and, in general, those of Europe (Oakeshott et al., 1982; Charles-Palabost, 1984; Izquierdo, 1987). That is, intermediate frequencies of the $\alpha G p d h-F$ and $\alpha G p d h-S$ alleles and very high frequency of the $A d h-F$ allele.

In most of the non-European populations the more frequent alleles are $\alpha G p d h-F$ and $A d h-S$ (Oakeshott et al., 1982; Charles-Palabost, 1984), their frequencies increasing towards the Equator. These alleles are associated with $\operatorname{In}(2 \mathrm{~L}) \mathrm{t}$ whose frequency also increases towards the Equator (Knibb, 1982 and references therein) although it seems that these latitudinal clines are not maintained exclusively by temperature (Malpica and Vassallo, 1980; Knibb, 1982; Oakeshott et al. 1982, 1984b; Kohane and Parsons, 1986).

It can be thought that allele frequencies at both loci persist in different populations by balacing equilibrium between fitness of alleles alone and, on the other hand, fitness of $\operatorname{In}(2 \mathrm{~L}) \mathrm{t}$, since the alleles having more fitness are $\alpha G p d h-S$ and $A d h-F$ according to their respective activity levels (Cluster et al., 1987), while $\operatorname{In}(2 \mathrm{~L}) \mathrm{t}$ is associated with the $\alpha G p d h-F$ and $A d h-S$ alleles.

So, towards the Equator we can expect the prevalence of near-optimal conditions (high and uniform temperature, abudance of food, abundance and diversity of laying places, etc.). Being so, the fitness of the $\alpha G p d h-S$ and $A d h-F$ alleles would not appear and, on the contrary, fitness of $\operatorname{In}(2 \mathrm{~L}) \mathrm{t}$ increases its frequency and therefore those of the $\alpha G p d h-F$ and $A d h-S$ alleles associated with it. On increasing the latitude, competitive conditions or, in general, restrictive conditions (lower and more variable temperatures, scarcity of food, scarcity of laying places, etc.) would prevail and the $\alpha G p d h-S$ and $A d h-F$ alleles having greater fitness in these conditions will increase their frequencies decreasing that of $\operatorname{In}(2 \mathrm{~L}) \mathrm{t}$ and the associated alleles.

This is in accordance with the observation (Izquierdo, 1987) that in the majority of natural populations, high or low relative frequency of alternative alleles of both loci ( $\alpha G p d h-F$ and $A d h$ $S$ or $\alpha G p d h-S$ and $A d h-F)$ coincide. That could also explain the close association between $\operatorname{In}(2 \mathrm{~L}) \mathrm{t}$ and $\alpha G p d h-F$ and $A d h-S$ alleles at low latitudes (Knibb, 1983; Inoue et al., 1984). However the $\operatorname{In}(2 \mathrm{~L}) \mathrm{t}$ clines is insufficient to explain the $\alpha G p d h$ and $A d h$ clines over relatively high latitudes 
(Voelker et al., 1978; Oakeshott et al., 1984b; Anderson et al., 1987) where $\operatorname{In}(2 \mathrm{~L}) \mathrm{t}$ is rare.

\section{REFERENCES}

AlAhiotis, S. AND PELECANOS, M. 1980. The effect of the environmental parameters temperature and humidity upon the variability of the gene pool in Drosophila melanogaster. Genetika, 12, 209-217.

ANDERSON, P. R., KNIBB, W. R. AND OAKESHOTT, J. G. 1987. Observations on the extent and temporal estability of latitudinal clines for alcohol dehydrogenase allozymes and four chromosome inversions in Drosophila melanogaster. Genetica, 75, 81 88.

BERGER, E. M. 1971. A temporal survey of allelic variation in natural and laboratory populations of Drosophila melanogaster. Genetics, 67, 121-136.

BRISCOE, D. A., ROBERTSON, A. AND MALPICA, J. M. 1975. Dominance at $A d h$ locus in response of adult Drosophila melanogaster to environmental alcohol. Nature, 255, 148149.

CAVENER, D. R. 1983. The response of enzyme polymorphisms to developmental rate selection in Drosophila melanogaster. Genetics, 105, 105-113.

CHARLES-PALABOST, L. 1982. Influence du milieu sur le maintien du polymorphisme de l' $\alpha$-glycérophosphate déshydrogénase chez Drosophila melanogaster. Arch. Zool. exp. géner., 122, 467-477.

CHARLES-PALABOST, L. 1984. Le système gène-enzyme de l' $\alpha$ glycérophosphate déshydrogénase chez Drosophila melanogaster. Génét. Sél. Evol., 16, 221-238.

CLUSTER, P. D., MARINKOVIC, D., AllaRD, R. W. AND AYAlA, F. J. 1987. Correlations between development rates, enzyme activities, ribosomal DNA spacer-length phenotypes and adaptation in Drosophila melanogaster. Proc. Natl Acad. Sci. USA, 84, 610-614.

CORRALES, E. 1982. Análisis de la variación génica en una población natural de Drosophila melanogaster. Tesis de Licenciatura. Universidad de Oviedo.

DAY, T. H., Hillier, P. C. AND ClARKe, B. 1974a. Properties of genetically polymorphic isozymes of alcohol dehydrogenase in Drosophila melanogaster. Biochem. Genet., 11, 141-153.

DAY, T. H., Hillier, P. C. AND ClARKE, B. $1974 b$. The relative quantities and catalytic activities of enzymes produced by alleles at the alcohol dehydrogenase locus in Drosophila melanogaster. Biochem. Genet., 11, 155-165.

DOBZHANSKY, T. 1970. Genetics of the Evolutionary Process. Columbia Univ. Press, New York.

GIBSON, J. B. 1970. Enzyme flexibility in Drosophila melanogaster. Nature, 227, 959-960.

GIBSON, J. B., MAY, T. W. AND wILKS, A. V. 1981. Genetic variation at the alcohol dehydrogenase locus in Drosophila melanogaster in relation to environmental variation: Ethanol levels in breeding sites and allozyme frequencies. Oecologia (Berl.), 51, 191-198.

GIBSON, J. B. AND WILKS, A. V. 1988. The alcohol dehydrogenase polymorphism of Drosophila melanogaster in relation to environmental ethanol, ethanol tolerance and alcohol dehydrogenase activity. Heredity, 60, 403-414.

GIONFRIDDO, M. A. AND VIGUE, C. L. 1978. Drosophila alcohol dehydrogenase frequencies and temperature. Genet. Res., Camb., 31, 97-101.
GRELL, E. H. 1967. Electrophoretic variants of $\alpha$-glycerophosphate dehydrogenase in Drosophila melanogaster. Science, $158,1319-1320$.

GRELL, E. H., JACOBSON, K. B. A.ND MURPHY, J. B. 1965 Alcohol dehydrogenase in Drosophila melanogaster: Isozymes and genetic variants. Science, 149, 80-82.

INOUE, Y., TOBARI, Y. N., TSUNO, K. AND WATANABE, T. K. 1984. Association of chromosome and enzyme polymorphisms in natural and cage populations of Drosophila melanogaster. Genetics, 106, 267-277.

IZQUIERDO, J. I. 1987. Polimorfismo aloenzimático en los loci $\alpha G p d h$ y $A d h$ en una población natural asturiana de Drosophila melanogaster. Rev. Biol. Univ. Oviedo, 5, 3-14.

KERVER, J. W. M. AND VAN DELDEN, W. 1985. Development of tolerance to ethanol in relation to the alcohol dehy. drogenase locus in Drosophila melanogaster. I. Adult and egg-to-adult survival in relation to ADH activity. Heredity, $55,355-367$.

KNIBB, W. R. 1982. Chromosome inversion polymorphisms in Drosophila melanogaster II. Geographic clines and climatic associations in Australasia, North America and Asia. Genetica, 58, 213-221.

KNIBB, W. R. 1983. Chromosome inversion polymorphisms in Drosophila melanogaster III. Gametic disequilibria and the contributions of inversion clines to the $A d h$ and $\alpha G p d h$ clines in Australasia. Genetica, 61, 139-146.

KNIBB, W. R., OAKESHOTT, J. G. AND WILSON, S. R. 1987. Chromosome inversion polymorphisms in Drosophila melanogaster IV. Inversion and $A d h$ allele frequency changes under selection for different development. Heredity 59, 95-104.

KOHANE, M. J. AND PARSONS, P. A. 1986. Environment-dependent fitness differences in Drosophila melanogaster: temperature, domestication and the alcohol dehydrogenase locus. Heredity, 57, 289-304.

LEVINE, L. AND SCHAWRTZ, N. M. 1970. Laboratory Exercises in Genetics. The C. V. Mosby Company, San Louis.

LEWON'TIN, R. C. 1974. The Genetic Basis of Evolutionary Change. Columbia Univ. Press, New York.

MALPICA, J. M. AND VASSALlo, J. M. 1980. A test of the selective origin of environmentally correlated allozyme patterns. Nature, 286, 407-408.

MARINKOVIC, D. AND AYALA, F. J. 1975a. Fitness of allozyme variants in Drosophila pseudoobscura. I. Selection at the Pgm-1 and Me-2 loci. Genetics, 79, 85-95.

MARINKOVIC, D. AND AYALA, F. J. 1975b. Fitness of allozyme variants in Drosophila pseudoobscura. II. Selection at the Est-5, Odh and Mdh-2 loci. Grenet. Res., Camb., 24, 137149.

McKECHNIE, S. W., KOHANE, M. A.ND PHILliPS, S. C. 1981. A search for interacting polymorphic enzyme loci in Drosophila melanogaster. In Gibson, J. B. and Oakeshott, J. G. (eds) Genetic Studies of Drosophila Populations, Australian Natl. Univ., Canberra.

McKeNZIE, J. A. AND McKeCHNIE, S. W. 1978. Ethanol tolerance and the $A d h$ polymorphism in a natural population of Drosophila melanogaster. Nature, 272, 75-76.

McKENZIE, J. A. AN D PARSONS, P. A. 1974. Microdifferentiation in a natural population of Drosophila melanogaster to alcohol in the environment. Genetics, 77, 385-394.

MILleR, S., PEARCY, R. V. AND BERGER, E. 1975. Polymorphism at the $\alpha$-glycerophosphate dehydrogenase locus in Drosophila melanogaster. I. properties of adult allozymes. Biochem. Genet., 13, 175-178.

MORGAN, P. 1975. Selection acting directly on a enzyme polymorphism. Heredity, 34, 124-127. 
NEI, M. 1975 Molecular Population Genetics and Evolution. American Elsevier, New York.

NEI, M. AND LI, W.-H. 1975. Probability or identical monomorphism in related species. Genet. Res., 26, 31-43.

NEI, M. AND LI, W.-H. 1980. Non-random association between electromorphs and inversion chromosomes in finite populations. Genet. Res., 35, 65-83.

OAKESHOTT, J. G. 1976. Selection at the alcohol dehydrogenase locus in Drosophila melanogaster imposed by environmental ethanol. Genet. Res., 26, 265-274.

OAKESHOTT, J. G., GIBSON, J. B., ANDERSON. P. R., KNIBB, W. R., ANDERSON, D. G. AND CHAMBERS, G. K. 1982. Alcohol dehydrogenase and glycerol-3-phosphate dehydrogenase clines in Drosophila melanogaster on different continents. Evolution, 36, 86-96.

OAKESHOTT, J. G., GIBSON, J. B. AND WILSON, S. R. 1984a. Selective effects of the genetic background and ethanol on the alcohol dehydrogenase polymorphism in Drosophila melanogaster. Heredity, 53, 51-67.

OAKESHOTT, J. G., McKECHNIE, S. W. AND CHAMBERS, G. K. $1984 b$. Population genetics of the metabolically related Adh, $\alpha G p d h$ and Tpi polymorphisms in Drosophila melanogaster 1. Geographic variation in $\alpha G p d h$ and Tpi allele frequencies in different continents. Genetica, 63, 2129.

OAKESHOTT, J. G., WILSON, S. R. AND PARNELL, P. 1985. Selective effects of temperature on some enzyme polymorphisms in laboratory population of Drosophila melanogaster. Heredity, 55, 69-82.

O'BRIEN, S. J. AND MacINTYRE, R. J. 1969. An analysis of gene-enzyme variability in natural populations of Drosophila melanogaster and D. Simulans. Am. Nat., 103, 97-113.

PRAKASH, S. AND LEWONTIN, R. C. 1968. A molecular approach to the study of genic heterozygosity in natural populations. III. Direct evidence of coadaptation in gene arrangements of Drosophila. Proc. Natl Acad. Sci. USA, 59, $398-405$

PRAKASH, S. AND LEWONTIN, R. C. 1971. A molecular approach to the study of genic heterozygosity in natural populations. V. Further direct evidence of coadaptation in inversions of Drosophila. Genetics, 69, 405-408.

RASMUSON, B., NILSON, L. R., RASMUSON, M. AND ZEPPEZAUER, E. 1966. Effects of heterozygosity on alcohol dehydrogenase (ADH) activity in Drosophila melanogaster. Hereditas, 56, 313-316.

ROCA, A., SANCHEZ REFUSTA, F., GRAÑA, C. AND COMENDADOR, M. A. 1982. Chromosomal polymorphism in a population of Drosophila melanogaster. Dros. Inf. Serv., 58, 130-131.
SANCHEZ, J. A. AND RUBio, J. Evolución del polimorfismo de loci enzimáticos en poblaciones experimentales de Drosophila melanogaster. I. El locus alcohol deshidrogenasa. Rev. Biol. Univ. Oviedo, 1, 3-9.

SANCHEZ, J. A. AND RUBIO, J. 1983b. Evolución del polimorfismo de loci enzimáticos en poblaciones experimentales de Drosophila melanogaster. 11. El locus $\alpha$-glicerofosfato deshidrogenasa. Rev. Biol. Univ. Oviedo, $1,11-17$.

SCHENFELD, E. AND MCKECHNIE, S. W. 1979. The $\alpha$ glycerophosphate dehydrogenase polymorphism in Drosophila melanogaster: Adult survival under temperature stress. Theor. Appl. Genet., 54, 235-237.

SERRADILLA, J. M. AND AYALA, F. J. 1983. Effects of allozyme variation on fitness components in Drosophila melanogaster. Genetica, 62, 139-146.

SOKAL, R. R. AND ROHLF, F. J. 1981. 'Biometry'. W. H. Freeman and Company, San Francisco.

VAN DELDEN, W., BOEREMA, A. C. AND KAMPING, A. 1978 The alcohol dehydrogenase polymorphism in populations of Drosophila melanogaster. 1. Selection in different environments. Genetics, 90, 161-191.

VAN DELDEN, W. AND KAMPING, A. 1979. The alcohol dehydrogenase polymorphism in populations of Drosophila melanogaster III. Differences in developmental times. Genet. Res., Camb., 33, 15-27.

VAN DELDEN, W. AND KAMPING, A. 1983. Adaptation to alcohols in relation to the alcohol dehydrogenase locus in Drosophila melanogaster. Entomol. Exp. Appl. 33: 97-102.

VIGUE, C. L. AND JOHNSON, F. M. 1973. Isozyme variability in species of the genus Drosophila. VI. Frequency-propertyenvironment relationships of allelic alcohol dehydrogenases in D. melanogaster. Biochem. Genet., 9, 213-227.

VIGUE, C. L., WEISGRAM, P. A. AND ROSENTHAL, E. 1982. Selection at the alcohol dehydrogenase locus of Drosophila melanogaster: Effects of ehtanol and temperature. Bioch. Genet., 20, 681-688.

VOELKER, R. A., COCKERHAM, C. C., JOHNSON, F. M., SCHAFFER, H. E., MUKAI, T. AND METTLER, L. E. 1978. Inversions fail to account for allozyme clines. Genetics, 88 , 515-527.

watanabe, T. K. AND watanabe, T. 1977. Enzyme and chromosome polymorphisms in Japanese natural populations of Drosophila melanogaster. Genetics, 85, 319-329.

WEIR, B. S. AND COCKERHAM, C. C. 1979. Estimation of linkage disequilibrium in randomly mating populations. Heredity, $42,105-111$. 